\title{
Decision making by NICE: examining the influences of evidence, process and context - CORRIGENDUM
}

KARIN H. CERRI, MARTIN KNAPP and JOSE-LUIS FERNANDEZ

doi:10.1017/S1744133113000030, published online by Cambridge University Press 21 May 2013.

There was an error made in the name of the author in the above published article. The author's name should have appeared as 'JOSÉ-LUIS FERNÁNDEZ'. This error has now been rectified in the original article.

\section{Reference}

Cerri, K. H., M. Knapp and J.-L. Fernández (2014), 'Decision making by NICE: examining the influences of evidence, process and context', Health Economics, Policy and Law, 9(2): 119-141. doi:10.1017/S1744133113000030. 